\title{
Recent increases in survival of western Steller sea lions in Alaska and implications for recovery
}

\author{
Lowell W. Fritz*, Rod Towell, Thomas S. Gelatt, Devin S. Johnson, \\ Thomas R. Loughlin
}

National Marine Mammal Laboratory, Alaska Fisheries Science Center, NOAA Fisheries, 7600 Sand Point Way NE, Seattle, Washington 98115, USA

\begin{abstract}
Survival rates of endangered western stock Steller sea lions Eumetopias jubatus east of Samalga Pass $\left(\sim 170^{\circ} \mathrm{W}\right)$ have rebounded to nearly the same levels estimated for the 1970 s prior to their decline in abundance. We estimated survival of sea lions hot-branded as pups $(\mathrm{N}=1449)$ in 2000-2005 using Cormack-Jolly-Seber mark-recapture models and sighting data collected through 2011. Survivorship to Age 7 yr was greater for females (range: 0.352-0.386) than males $(0.228-0.275)$, but was similar for each sex across the study area. Survival was lowest in the first year and increased through Age $4+\mathrm{yr}$ for both sexes in the eastern Gulf of Alaska $\left(144-150^{\circ} \mathrm{W}\right)$. However, to the west, first-year survivorship was greater or equal to that of Year 2, and the difference was generally greater for males than females. Regional differences in the pattern of early survival could reflect spatial variability in early life history (e.g. duration of maternal care, growth rate) or habitat characteristics (e.g. prey availability, rates of predation). Population models indicate that natality of the increasing population east of Samalga Pass in 2000-2012 may not be significantly different from rates estimated for the 1970s prior to the decline in overall western abundance. Given current information, western Steller sea lions may satisfy the stock-wide demographic down-listing (to threatened status) criterion by 2015. However, due to continued abundance declines west of Samalga Pass, where no survival data are currently available, it is less certain that the western stock's regional down-listing criteria will be achieved.
\end{abstract}

KEY WORDS: Steller sea lion · Alaska $\cdot$ Branding $\cdot$ Survival

\section{INTRODUCTION}

The Steller sea lion Eumetopias jubatus inhabits the North Pacific Ocean, breeding and giving birth on terrestrial rookery sites ranging from central California north and west through British Columbia, Alaska, and Russia, including the Aleutian and Kuril Islands, along the Kamchatka Peninsula, and in the Sea of Okhotsk (NMFS 1992, 2008, Burkanov \& Loughlin 2005) (Fig. 1). The Steller sea lion is one of the most studied marine mammals of the past $20 \mathrm{yr}$ (Ferrero \& Fritz 2002), largely because of a steep decline in abundance in the 1980s, its listing as 'threat-

${ }^{*}$ Corresponding author: lowell.fritz@noaa.gov ened' under the US Endangered Species Act (ESA) in 1990, and the potential for competitive overlap with some of the largest fisheries in the USA to affect its recovery (Fritz et al. 1995, NMFS 2008, 2010). Genetic, distribution, and population trend data led the National Marine Fisheries Service (NMFS) to separate the species into 2 stocks for management purposes in 1997 (Bickham et al. 1996, Loughlin 1997). The eastern stock, which breeds on rookeries east of $144^{\circ} \mathrm{W}$, retained its 'threatened' status under the ESA, but increased at $>3 \%$ per year since the 1970 s following the cessation of predator control and commercial harvesting activities, and was removed from

Outside the USA @ The US Government 2014. Open Access under Creative Commons by Attribution Licence. Use, distribution and reproduction are unrestricted. Authors and original publication must be credited. Publisher: Inter-Research - www.int-res.com 

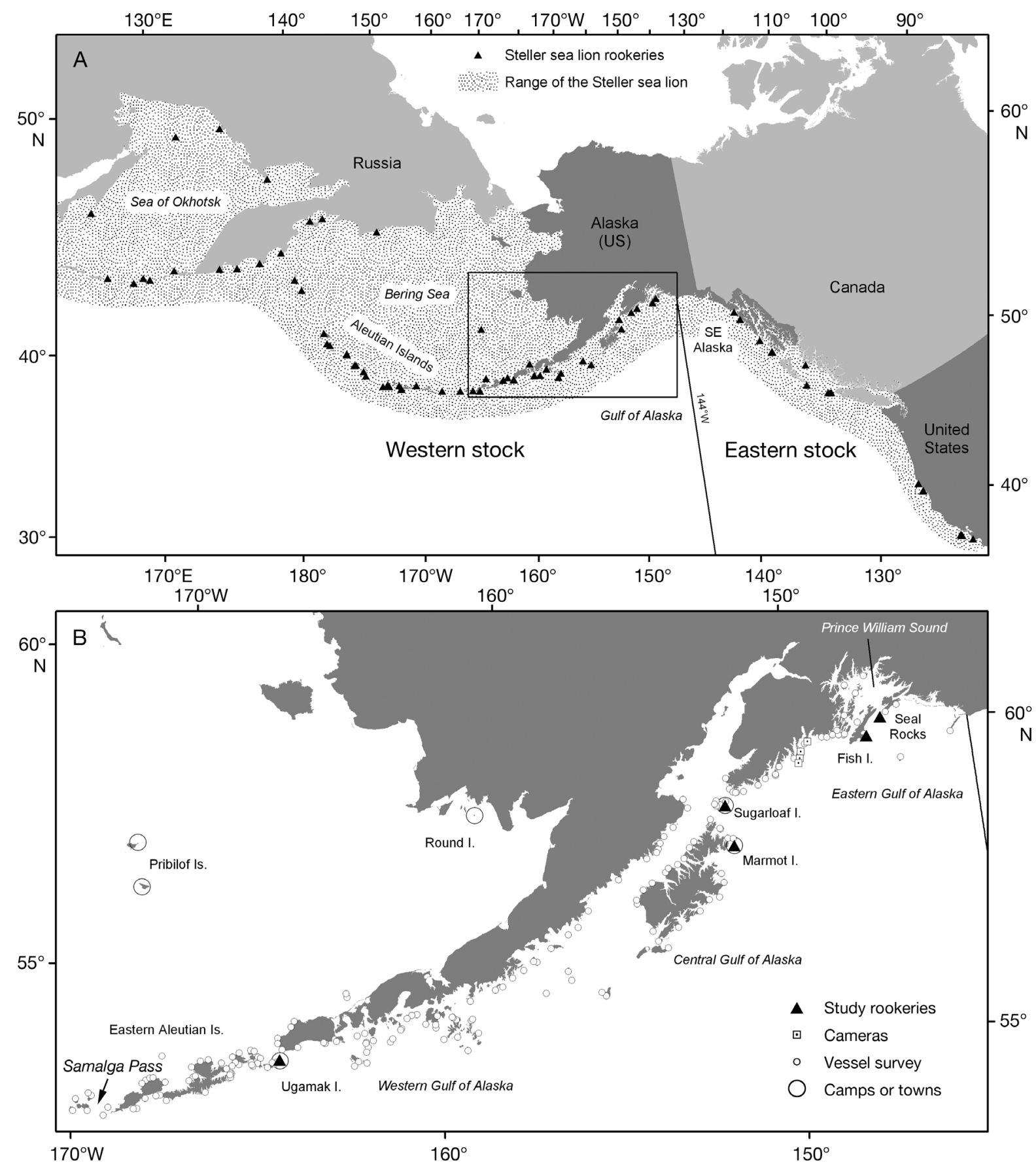

Fig. 1. (A) Location of study area (box; B) within the range of the western stock of Steller sea lion (Eumetopias jubatus) in Alaska, USA. Sea lions in the eastern and western stocks breed at rookeries ( $\mathbf{\Delta}$ ) east and west of $144^{\circ} \mathrm{W}$, respectively. (B) Steller sea lion rookeries where pups were hot-branded, June-July 2000-2005, along with rookery and haul-out sites surveyed for branded animals in May-August 2001-2011 during vessel surveys, using in situ cameras, or by land-based observers at field camps or living in nearby towns

ESA protection in 2013 (Pitcher et al. 2007, NMFS 2013). The status of the western stock was changed to 'endangered' in 1997 because of persistent declines in counts of newborn pups and animals $1 \mathrm{yr}$ and older (adults and juveniles, or non-pups; NMFS 2008).
Demographic analyses (York 1994, Holmes \& York 2003, Fay \& Punt 2006, Pendleton et al. 2006, Winship \& Trites 2006, Holmes et al. 2007) have largely attributed the western stock decline in the 1980s to a steep, sudden drop in juvenile survival, but adult sur- 
vivorship and natality (average annual probability that an adult female will give birth to a live pup) were also likely to have been negatively affected (Holmes \& York 2003; Holmes et al. 2007). The decline was first noted in the late 1970s in the eastern Aleutian Islands (Braham et al. 1980; Fig. 1), but spread both east and west in the 1980s, when the steepest overall rates of decline $\left(\sim 15 \% \mathrm{yr}^{-1}\right)$ were observed (Loughlin et al. 1992). Coincident with the listing of the species under the ESA and the implementation of new regulations to reduce direct human-related mortality (Fritz et al. 1995), the rate of decline in the overall population slowed in the 1990s, but differences in regional trends emerged (York et al. 1996); the population stabilized in the center of its Alaska range (eastern Aleutian Islands and western Gulf of Alaska), but continued to decline at the ends of the range in the eastern-central Gulf of Alaska and western-central Aleutian Islands (Fritz et al. 2013). The western population in Alaska ceased declining in 2000, and a modest increase in abundance was observed through 2012, driven largely by increases east of Samalga Pass, while counts in most regions west of Samalga Pass continued to drop (Fritz et al. 2013).

Pitcher \& Calkins (1981) provide a detailed description of the reproductive biology of the Steller sea lion. The breeding season (pupping and mating) of Steller sea lions is relatively short and synchronous, likely due to the strong seasonality of the environment in the Bering Sea and North Pacific Ocean and the need to balance aggregation for reproductive purposes with dispersion to avoid intra-specific competition for food resources (Bartholomew 1970). Adult males establish breeding territories on rookeries beginning in mid-late May, followed shortly by the arrival of adult females. Parturition usually occurs within days of arrival at the rookery (between late May and early July), with the mean birth dates varying between 9 and 14 June within the longitudinal range of this study $\left(147-165^{\circ} \mathrm{W}\right.$; Pitcher et al. 2001). Pregnant females generally give birth to a single pup; twinning occurs, but is rare (Maniscalco \& Parker 2009). Though biased slightly toward greater production of males, the sex ratio of pups at birth is approximately 1:1 (Pike \& Maxwell 1958, Lowry et al. 1982).

The life history of a Steller sea lion through Age $11 \mathrm{yr}$ is different for females and males. For females, Pitcher \& Calkins (1981) reported mean ages of first ovulation and pregnancy of 4.6 and $4.9 \mathrm{yr}$, respectively, based on examination of collected (sacrificed) animals. Ovulation rates increased from $26 \%$ at $3 \mathrm{yr}$ to $100 \%$ at $\geq 6 \mathrm{yr}$, while pregnancy rates increased from $20 \%$ at $3 \mathrm{yr}$ to $87 \%$ for females aged 8 to $20 \mathrm{yr}$. Sexual and social maturity in males is achieved at different ages, with sexual maturity occurring first (at 5-7 $\mathrm{yr}_{\text {; }}$ Winship et al. 2001), followed by social maturity (at 9-13 yr; Thorsteinson \& Lensink 1962, Winship et al. 2001, Raum-Suryan et al. 2002) once males have grown large enough to defend breeding territories.

Here we report estimates of juvenile $(\leq 3 \mathrm{yr})$ and young adult (4-11 yr) survival rates based on observations of Steller sea lions hot-branded as pups on 5 western rookeries from 2000 through 2005. These are the first age-specific survival rates for western Steller sea lions born after the stock was listed as endangered in 1997 that were directly estimated from sightings of marked individuals. Our objective is to relate changes in survival to changes in abundance between the 1970s and 2000s, as well as discuss the relationship between vital rates (survivorship, natality, and movement) and regional abundance trends in the 2000s (Fritz et al. 2013, Johnson \& Fritz 2014).

\section{MATERIALS AND METHODS}

\section{Marking}

Steller sea lion pups were individually marked (hot-branded) at 2-5 wk of age in late June or early July each year from 2000 through 2005 on 5 western rookeries in Alaska (Table 1, Fig. 1). Two of the rookeries (Seal Rocks and Fish Island) are located south of Prince William Sound in the eastern Gulf of Alaska, 2 (Marmot and Sugarloaf Islands) are in the central Gulf of Alaska near Kodiak Island, and 1 (Ugamak Island) is in the eastern Aleutian Islands. Mean sea lion birth dates range between 9 June (at Marmot Island) and 14 June (at Fish Island) at the study rookeries (Pitcher et al. 2001), and branding dates ranged from 24 June to 6 July. Pups were marked by hotbranding a letter corresponding to the natal rookery (J, Seal Rocks; E, Fish; X, Sugarloaf; T, Marmot; A, Ugamak) followed by a unique 1- to 3-digit number starting on the left shoulder and extending down the left side (Fig. 2A) using the methods of Merrick et al. (1996). All pups were weighed, measured (length), and immobilized using gas (isoflurane) anesthesia prior to branding. A minimum pup weight of $20 \mathrm{~kg}$ was established to avoid branding a very young animal shortly after birth. Since we do not know birth dates, setting a minimum weight for branding could 
Table 1. Number of Steller sea lion pups branded by cohort, sex, rookery and region. Gaps indicate 0 pups branded

\begin{tabular}{|c|c|c|c|c|c|c|c|c|c|c|c|c|c|c|c|c|}
\hline \multirow[t]{3}{*}{ Rookery } & \multirow[t]{3}{*}{ Region } & & & & & & & \multicolumn{9}{|c|}{ Cohort and sex } \\
\hline & & \multicolumn{2}{|c|}{2000} & \multicolumn{2}{|c|}{2001} & \multicolumn{2}{|c|}{2002} & \multicolumn{2}{|c|}{2003} & \multicolumn{2}{|c|}{2004} & \multicolumn{2}{|c|}{2005} & \multicolumn{3}{|c|}{ Totals } \\
\hline & & $\mathrm{F}$ & $\mathrm{M}$ & $\mathrm{F}$ & $\mathrm{M}$ & $\mathrm{F}$ & $\mathrm{M}$ & $\mathrm{F}$ & $\mathrm{M}$ & $\mathrm{F}$ & $\mathrm{M}$ & $\mathrm{F}$ & $\mathrm{M}$ & $\mathrm{F}$ & M & Total \\
\hline Seal Rocks & Eastern Gulf & & & 34 & 41 & & & 44 & 56 & & & 34 & 46 & 112 & 143 & 255 \\
\hline Fish Isl. & Eastern Gulf & & & 17 & 15 & & & & & & & & & 17 & 15 & 32 \\
\hline Sugarloaf Isl. & Central Gulf & 78 & 73 & & & 43 & 62 & & & 51 & 59 & & & 172 & 194 & 366 \\
\hline Marmot Isl. & Central Gulf & 48 & 59 & & & 50 & 39 & & & 37 & 38 & & & 135 & 136 & 271 \\
\hline Ugamak Isl. & Eastern Aleutians & & & 79 & 96 & & & 70 & 80 & & & 90 & 110 & 239 & 286 & 525 \\
\hline Total & Total & 126 & 132 & 130 & 152 & 93 & 101 & 114 & 136 & 88 & 97 & 124 & 156 & 675 & 774 & 1449 \\
\hline
\end{tabular}
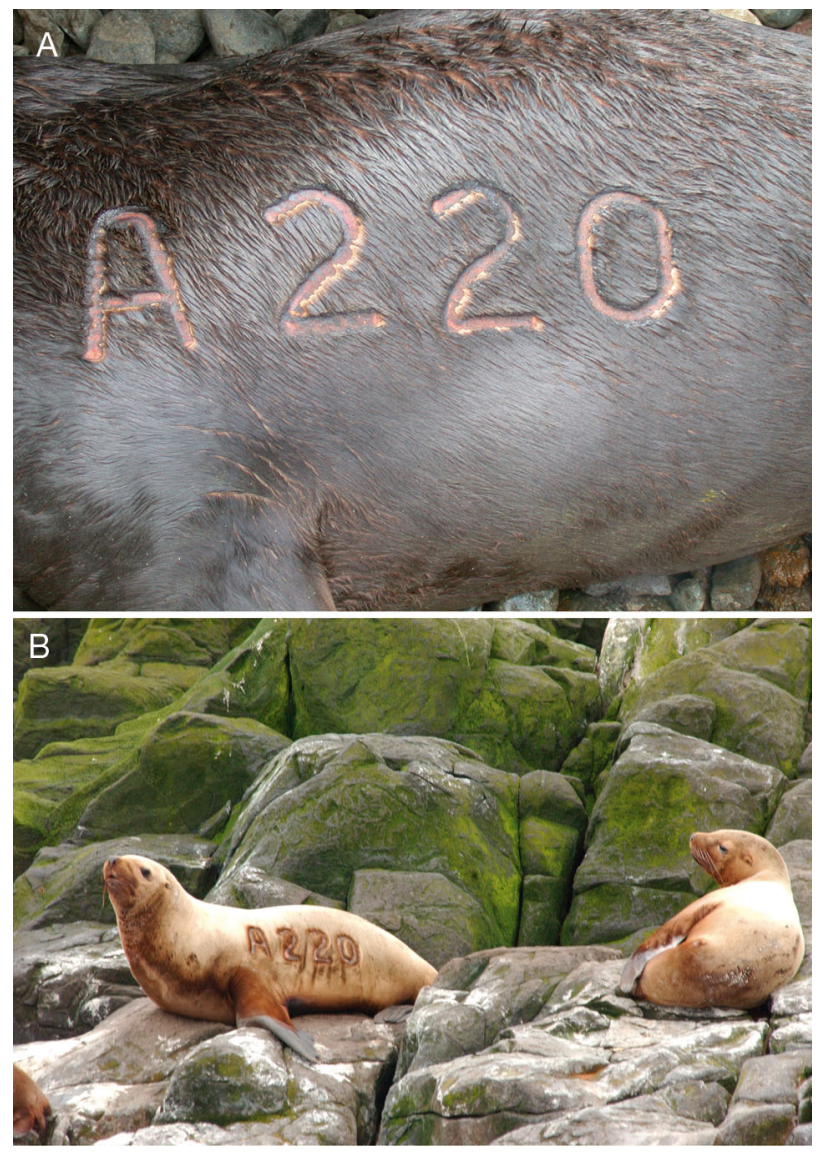

Fig. 2. (A) Brand 'A220' as applied on left side of $~ 1$-mo-old male Steller sea lion on 24 June 2003, Ugamak Island. (B) 'A220' at 11 mo old on 19 May 2004 at Clubbing Rocks, $\sim 130 \mathrm{~km}$ east of Ugamak Island

bias our results toward those pups with greater birth weights and possibly higher survival (Hastings et al. 2009). We do not know the magnitude of this bias. The total duration that an individual pup was handled (measuring and branding) was approximately $5 \mathrm{~min}$. The rookery was disturbed by human presence on land for between 6 and $9 \mathrm{~h}$ (see Wilson et al. 2012 for an analysis of the effects of the disturbance caused by pup branding on adult and juvenile sea lions at the rookery). Other studies (e.g. Mellish et al. 2007, Hastings et al. 2009) have shown that branding has little to no measurable impact on health or shortterm (12-wk) survival of juveniles or pups.

\section{Observation and identification of marked animals}

Observations of branded animals made from 1 May through 31 August (2001-2011) were used in the analysis (Fig. 2B). Sightings during the remainder of the year were excluded in an effort to conform to the 'instantaneous' observation assumption of CormackJolly-Seber (CJS) open population models used to estimate survival and sighting probabilities. We acknowledge that we have not entirely met this assumption, and that mortalities are likely to have occurred during our sighting period. For instance, $25 \%$ of the 12 Steller sea lion mortalities detected in 6 yr by Horning \& Mellish (2012) using implanted 'life history transmitter' tags occurred in MayAugust. This would affect age-specific survival estimates during short studies with few years of sightings, but be mitigated in longer studies such as ours with $11 \mathrm{yr}$ of sightings. Sighting effort consisted of: (1) small boat-based surveys lasting between $1 \mathrm{wk}$ and $1 \mathrm{mo}$; (2) land-based observations by observers at field camps on Marmot and Ugamak Islands from late May through early August each year; (3) landbased opportunistic observations by northern fur seal (Callorhinus ursinus) researchers and residents of the Pribilof Islands; (4) land-based opportunistic observations by USFWS scientists on Round Island in Bristol Bay, eastern Bering Sea, or throughout the Aleutian Islands and Gulf of Alaska; (5) photographs or video taken by cameras operated by the Alaska Sea Life Center, Seward, AK (Maniscalco et al. 2010), mounted above 4 Steller sea lion haul-out and rookery sites (Fig. 1B); and (6) observations by collaborating scientists working in Russia and southeast Alaska 
(Fig. 1A). In 2006, there was no field camp at Ugamak Island, the Marmot Island field camp was limited to the month of July, and there was reduced sighting effort expended overall in the USA because of a court-ordered injunction on most Steller sea lion research (Dalton 2005).

A branded animal must have been unambiguously identified to be included as a sighting in the recapture history. Observers recorded each brand character and a code indicating the quality of the identification and of the character/digit itself on the animal. A recapture of a marked animal was defined as a sighting only if each character or digit was clearly identified. Field identifications of marked animals were supported by high-resolution digital photographs in $99 \%$ of the individual sightings per year (Fig. 2B).

\section{Estimation of sighting probability and survival rates}

We used CJS open population mark-recapture models to estimate sighting probability $(p)$ and apparent annual survival $(\Phi)$. Apparent annual survival is estimated and differs from true survival because death, mark loss, and permanent emigration from the study area cannot be distinguished from each other. However, for conciseness, we will use only 'survival' when discussing $\Phi$. All analyses were conducted using the program MARK 4.3 (White \& Burnham 1990); data input and model formulation were facilitated with the $\mathrm{R}$ statistical environment (R Development Core Team 2013) and the add-on package RMark (Laake \& Rexstad 2007).

The factors age, sex, time (year), rookery, and region were used to model $p_{\text {; }}$ age, sex, cohort (time; only for $\Phi$ in Year 1 as pup:time), rookery, and region were used to model $\Phi$ (see legend to Table 2 for explanation of model notation). Regions were used in the model because of differences in regional population trends and the strong similarity in trends at each of the 2 rookeries in the eastern and central Gulf of Alaska regions since the mid-1970s (York et al. 1996, Fritz et al. 2013). Pooled estimates by region could also yield more precise estimates of $\Phi$.

Preliminary models were run to determine which factors and combinations were the most influential in estimating $\Phi$ and $p$. Initial runs were used to select the best $p$ model (sex:time:region); this was then used to find the best combinations of factors to model $\Phi$. All combinations of factors for $\Phi$ were run, along with several age bin schemes (e.g. 1, 2, 3, 4+ yr; 1, 2, $3,4,5,6-7,8+\mathrm{yr}_{i} 1,2,3,4-5,6-7,8+\mathrm{yr}_{i} 1,2,3,4$,
$5-7,8+$ yr). Preliminary $\Phi$ model runs revealed that survival generally increased during the first $3 \mathrm{yr}$, and then was relatively stable and high for Ages $4+\mathrm{yr}$ for both sexes. Once this age bin structure $(1,2,3,4+$ yr $)$ was selected, a total of $17 \Phi$ models (using sex, age, region, rookery, and cohort) were run. Models were compared using Akaike's information criterion corrected for small sample size $\left(\mathrm{AIC}_{\mathrm{c} i}\right.$ Burnham \& Anderson 2002). Our estimate $\hat{C}$ (over-dispersion parameter; Burnham \& Anderson 2002) was less than 3 , indicating that there were likely only minor violations of assumptions regarding independence and parameter homogeneity among individual marked animals. As such, $\mathrm{AIC}_{\mathrm{c}}$ rather than quasi-AIC $\mathrm{Al}_{\mathrm{c}}$ was used in model selection.

We developed an age-sex-structured population model (Leslie matrix) using current western regional survival (present study) and varying natality (see Holmes et al. 2007). We did this so we could estimate natality for the 2000-2012 period using current survival (from branding) and rates of population change (non-pup trends) from aerial surveys (Fritz et al. 2013, Johnson \& Fritz 2014). Using the new survival estimates from this study, an initial age-specific reproductive rate array was adjusted with a tuning parameter so that the regional growth of the agestructured population would match current regional non-pup trends (Fritz et al. 2013, Johnson \& Fritz 2014). To complete the survival schedule for Ages 12-31 yr, we matched the ratio of the survival decline in the schedule of the 1970s (stable) population in Appendix C of Holmes et al. (2007). That is to say, for age $a>11 \mathrm{yr}$, the following survival $(\Phi)$ was used:

$$
\Phi_{a}=\Phi_{11}\left(\frac{\Phi_{a}^{*}}{\Phi_{11}^{*}}\right)
$$

where $\Phi_{a}^{*}$ is the age a survival from the 1970 s schedule (Holmes et al. 2007). The natality schedule was modeled as in Holmes et al. (2007), i.e.:

$$
f_{a}=\min \left(1, \omega f_{a}^{*}\right)
$$

where $f_{a}$ is the natality at age $a_{1} f_{a}^{*}$ is the natality from the 1970s stable population (Holmes et al. 2007), and $\omega$ is a tuning parameter to vary in order to obtain the desired population growth of non-pups for the 2000-2012 period for the 3 regions (Table 1, Table S1 in the Supplement at www.int-res.com/articles/suppl/ n026p013_supp.pdf). To obtain estimates of $\omega$, we used the method of Conn et al. (2014) to create a simulated population of aerial surveys where $\omega$ is optimized to create trend estimates close to the observed trend estimates in each region using a sum-of- 
squares objective function. In order to account for uncertainty in the observed trend estimates from Fritz et al. (2013) and Johnson \& Fritz (2014), the same procedure was used to obtain $\omega$ values for the upper and lower $95 \%$ credible interval (CI) of the observed trend estimate. Thus, we have an approximate $95 \%$ CI for $\omega$ based on the posterior distribution of the observed trend estimates. If 1 is contained within the CI of $\omega$ for a region, then we would conclude that there is not strong evidence that 20002012 regional natality is different from that estimated for the 1970s central Gulf of Alaska population. We assumed a stable age distribution for the initial year (2000) for each regional model run, and closed regional populations. A combined eastern-central Gulf region was also formed because movement of branded animals during the breeding season from the central to the eastern region suggested that neither population was closed, and that movement may have affected regional trend estimates (Table S1 in the Supplement). Survival-at-age estimates for the combined eastern-central Gulf region were obtained by running a separate $\Phi$ [sex ${ }^{*}$ age], $p$ [sex:time: region] model using only data for pups branded on Seal Rocks, Fish, Marmot, and Sugarloaf (Table 1, Table S2 in the Supplement).

To obtain pooled estimates of survival-at-age by sex for the 4 southeast Alaska rookeries where Hastings et al. (2011) branded pups, we calculated a weighted average (without confidence bounds) based on individual rookery pup production in 2009 (Fritz et al. 2013) and assumed an even sex ratio (Pike \& Maxwell 1958, Lowry et al. 1982). Using the weighted average survival-at-age values, we then estimated survivorship through Age $7 \mathrm{yr}$ for both females and males for comparison with the western population. sex:region interactions that were not evident with more fine-scale age bin structures. Interactive models for $p$ and $\Phi$ allowed regional, temporal, and ageand sex-related effects to vary independently.

Sighting probability was generally higher for females than males, and increased from 2007 through 2011 for both sexes as the branded population matured and recruited to rookeries (Fig. S1 in the Supplement). Given that sightability generally increased with time, we thought age would be included as well, but it appears to have been overwhelmed by time and region in the best $p$ model. Logistical and other factors (e.g. cruise schedules, weather) were chiefly responsible for the time:region effect on $p$, since they affected the specific sites visited each year. In addition, the effect of significantly reduced sighting effort led to low $p$ values in 2006, particularly in the eastern Gulf of Alaska. Age was the most important factor used to model $\Phi$, appearing in each of the top 15 models, followed by sex and region (Table 2). Cohort effects were not in any of the top 5 models (with $>99 \%$ of the combined weight of all models), and rookery effects only appeared in the second highest rated model (with only $7.2 \%$ of the weight).

Regional effects on survival were largely expressed during the first $3 \mathrm{yr}$ for both females and males (Table 3). Survival rates at Age 1 yr were lowest in the eastern Gulf of Alaska, and were not significantly different $(p>0.05)$ between females and males. Female survival at Age 1 yr was significantly greater $(p<0.05)$ in the central Gulf of Alaska and eastern Aleutian Islands than in the eastern Gulf of Alaska (Table 3, Fig. 3). In the central Gulf, female survival rates during each of the first 3 years were similar, ranging between 0.76 and 0.79 , while for males, point estimates dipped from 0.79 at Age 1 yr to

\section{RESULTS}

Despite having the largest number of estimated parameters, the interactive models [sex:time:region] and [sex:age:region] provided the best combination of factors (had the lowest $\mathrm{AIC}_{\mathrm{c}}$ and $>90 \%$ of the weight of all models) to model $p$ and $\Phi$, respectively (Table 2 ). Using the simplest bin scheme $(1,2,3,4+y r)$ rather than one that estimated more age-specific survivorships (e.g.: 1, 2, 3, 4, 5, 6-7, and 8-10 yr) greatly improved overall fits $\left(\Delta \mathrm{AIC}_{\mathrm{c}}=15.9\right.$ between top models) and revealed strong
Table 2. Top 5 models (with $>99 \%$ of the weight of all models) used to estimate survival $(\Phi)$ and sightability $(p)$ of branded western Steller sea lions in Alaska. Model 1 was used to estimate $\Phi$ and $p$. Weight: relative strength of model compared with all other models; $\Delta \mathrm{AIC}_{\mathrm{c}}$ : difference in $\mathrm{AIC}_{\mathrm{c}}$ (Burnham \& Anderson 2002) relative to the top-weighted model. Model factors: (:) interaction terms without main effects; $\left({ }^{*}\right)$ interaction terms with main effects; $(+)$ additive main effects only

\begin{tabular}{|lcrc|}
\hline Model & Weight & $\Delta \mathrm{AIC}_{\mathrm{c}}$ & $\begin{array}{c}\text { No. para- } \\
\text { meters }\end{array}$ \\
\hline 1. $\Phi$ (sex:age:region) $p$ (sex:time:region) & 0.909 & & 86 \\
2. $\Phi$ (age:rookery) $p$ (sex:time:region) & 0.072 & 5.1 & 82 \\
3. $\Phi$ (age:region) $p$ (sex:time:region) & 0.004 & 10.8 & 74 \\
$4 . \Phi\left(\right.$ sex ${ }^{*}$ age) $p$ (sex:time:region) & 0.004 & 11.0 & 70 \\
$5 . \Phi($ sex + age) $p$ (sex:time:region) & 0.003 & 11.2 & 67 \\
\hline
\end{tabular}


Table 3. Age- and sex-specific survival estimates ( $\Phi$ and $95 \%$ confidence interval, $C I$ ) of branded western Steller sea lions in Alaska by region, sex, and age. Average $\Phi$ was estimated for Ages 4+ yr

\begin{tabular}{|c|c|c|c|c|c|c|c|c|c|c|c|c|}
\hline \multirow{3}{*}{$\begin{array}{l}\text { Age } \\
\text { (yr) }\end{array}$} & \multicolumn{4}{|c|}{ — Eastern Gulf of Alaska } & \multicolumn{4}{|c|}{ — Eastern Aleutian Islands } & \multicolumn{4}{|c|}{ — Central Gulf of Alaska } \\
\hline & \multicolumn{2}{|r|}{ Females } & \multicolumn{2}{|c|}{ Males } & \multicolumn{2}{|c|}{ Females } & \multicolumn{2}{|c|}{ Males } & \multicolumn{2}{|c|}{ Females } & \multicolumn{2}{|c|}{ Males } \\
\hline & $\Phi$ & $95 \% \mathrm{CI}$ & $\Phi$ & $95 \% \mathrm{CI}$ & $\Phi$ & $95 \% \mathrm{CI}$ & $\Phi$ & $95 \% \mathrm{CI}$ & $\Phi$ & $95 \% \mathrm{CI}$ & $\Phi$ & $95 \% \mathrm{CI}$ \\
\hline 1 & 0.555 & $0.450-0.656$ & 0.6 & $0.476-0.713$ & 0.785 & $0.682-0.861$ & 0.873 & $0.700-0.953$ & 0.779 & $0.697-0.844$ & 0.789 & $0.688-0.863$ \\
\hline 2 & 0.913 & $0.645-0.984$ & 0.67 & $0.498-0.806$ & 0.738 & $0.626-0.826$ & 0.574 & $0.465-0.677$ & 0.757 & $0.646-0.841$ & 0.692 & $0.563-0.797$ \\
\hline 3 & 0.935 & $0.712-0.988$ & 0.834 & $0.621-0.939$ & 0.945 & $0.795-0.987$ & 0.899 & $0.739-0.965$ & 0.788 & $0.684-0.865$ & 0.726 & $0.597-0.826$ \\
\hline $4-10$ & 0.95 & $0.905-0.974$ & 0.913 & $0.838-0.955$ & 0.896 & $0.859-0.924$ & 0.883 & $0.845-0.913$ & 0.938 & $0.913-0.956$ & 0.871 & $0.834-0.901$ \\
\hline
\end{tabular}

0.69 and 0.72 at Ages 2 and $3 \mathrm{yr}$, respectively. In the eastern Aleutians, female survival rates at Ages 1 and 2 yr were similar, while male survival was significantly greater $(\mathrm{p}<0.05)$ at Age $1 \mathrm{yr}$ than at Age $2 \mathrm{yr}$ (Table 3). At Age $3 \mathrm{yr}$ in the eastern Aleutians, both female and male survival increased to rates that were not significantly different $(p>0.05)$ from those at Ages $4+$ yr. Survival rates at Ages 4+ yr were generally the highest for both sexes and generally higher for females than males within each region.

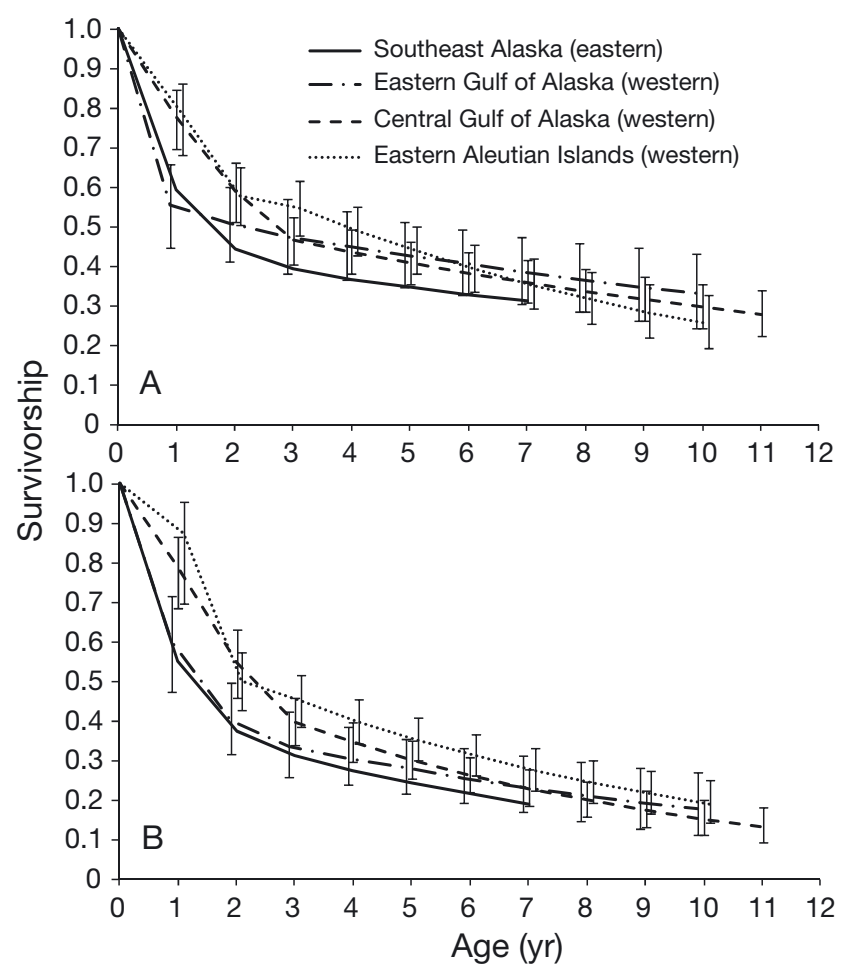

Fig. 3. Survivorship (proportion born surviving to age) of (A) female and (B) male Steller sea lions branded as pups at rookeries in Alaska: western stock (eastern and central Gulf of Alaska, and the eastern Aleutian Islands; present study) and eastern stock (southeast Alaska; Hastings et al. 2011). Legend in A also applies to B. Confidence bounds (95\%) are plotted at Age -0.1 and +0.1 yr for the eastern Gulf of Alaska and eastern Aleutian Islands regions, respectively, and at the integer year for the central Gulf of Alaska
Despite much lower Age $1 \mathrm{yr}$ survival rates in the eastern Gulf (Table 3), survivorship of females to Age 4 and 8 yr (age of first birth and age at the beginning of the period with peak natality; Pitcher \& Calkins 1981, Calkins \& Pitcher 1982, Holmes et al. 2007) were similar between regions, ranging between $0.44-$ 0.49 and $0.32-0.37$, respectively (Fig. 3A). Similarly, survivorship of males to age of social maturity ranged between 0.17 and 0.21 (Fig. 3B), despite large regional differences in Ages 1-3 yr survival (Table 3).

Based on our Leslie matrix model, current (20002012) estimated natality in the eastern Gulf $(\omega=0.97$, $95 \%$ credible interval of $0.68-1.34$ ) is not significantly different from the 1970 s baseline rate (Holmes et al. 2007), but remains low in the central Gulf $(\omega=$ $0.81,0.69-0.94)$. Combining these 2 regions yielded an estimate of $\omega(0.87,0.72-1.03)$ that was $13 \%$ lower than, but not significantly different from, the 1970s. Estimated current natality in the eastern Aleutian Islands is $9 \%$ higher that that of the $1970 \mathrm{~s}(\omega=1.09$, $0.92-1.28)$, but also not significantly different.

\section{DISCUSSION}

Pendleton et al. (2006) reported higher Age $1 \mathrm{yr}$ than Age 2 yr survival rates in western Steller sea lions based on sightings of animals branded as pups on Marmot Island in the central Gulf of Alaska in 1987-1988. In contrast to our study, they found little difference in survival-at-age between the sexes, but this could be the result of a smaller sample size and lower overall sighting probability than in our study. We report that female western Steller sea lions in the western part of our study area have high Age 1 yr survival and no difference in survival between Ages 1 and 2 yr. Males in this same region also have high Age 1 yr survival but greater survival at Age 1 yr than Age $2 \mathrm{yr}$, with this difference being much larger to the west. However, western sea lions in the eastern part of our study area have a pattern of Age 1-2 yr survival that is similar to that of eastern stock sea 
lions in southeast Alaska (Hastings et al. 2011) and other otariid pinnipeds (e.g. Arctocephalus gazella, Boyd et al. 1995; A. pusillus pusillus, Butterworth et al. 1995; Zalophus californianus, Hernandez-Camacho et al. 2008; Callorhinus ursinus, Lander 1981-1982) in which $\Phi$ is lowest during the first year and increases with age.

Low sightability of the 2004 and 2005 branded western cohorts due to reduced effort in 2006 and heterogeneity in sighting probability of young branded sea lions could have affected the regional pattern of Age 1-2 yr survivorships. To test for the former, we ran Model 1 (Table 1) with only the 20002003 cohorts; the regional survivorship pattern was unchanged and the survival estimates were not significantly different ( $p>0.05)$. However, heterogeneity in sighting probabilities may be contributing to this early survival pattern. Regions with relatively high Year 1 survival were also those where field camps were manned for several months each summer, increasing the likelihood that a branded juvenile would be seen if it were still not fully independent from its mother at Ages 1 and 2 yr. Conversely, less effort at rookeries in regions without field camps (eastern Gulf of Alaska) may have led to fewer observations of the same branded animal at both Ages 1 and 2 yr. As such, the model may have not been able to partition survival between the first 2 yr here compared with the more western regions, and this may be evidenced by the larger standard errors, particularly for Age 2 yr. However, where we may have our best sighting data, the pattern of survival during the first 2 yr appears to be different in the 2 stocks (Hastings et al. 2011), suggesting differences in Steller sea lion life history. High Age 1 yr survival in the west could be the result of longer average periods of maternal care, lower predation rates (see Horning \& Mellish 2012), or a combination of these and other factors compared with the eastern stock. While our results suggest that the eastern Gulf of Alaska has a pattern more similar to that of southeast Alaska, heterogeneity and logistical issues related to sighting probability preclude this from being a firm conclusion at this point.

In general, our estimates of western Steller sea lion survival rates are higher than those estimated for eastern sea lions in southeast Alaska, particularly from the southern, larger, and older rookeries at Forrester and Hazy Islands (Hastings et al. 2011). Age 1 yr survival of pooled eastern females was nearly identical to western females in the eastern Gulf of Alaska, but was lower than western females in the central Gulf of Alaska and eastern Aleutian
Islands (Fig. 3A). Western female survivorships to Age 5 yr (range of 0.41 to 0.44 for the 3 regions) were similar and were all generally greater than the estimate for pooled eastern females $(0.34$; Fig. 3A). Western male survivorship to Age 5 yr was greater in the eastern Aleutian Islands (0.35) than in either of the other western regions (eastern and central Gulf of Alaska, 0.28 and 0.30 , respectively) or southeast Alaska (eastern stock, 0.24; (Fig. 3B).

A result common to all demographic modeling studies of the dynamics of the western Steller sea lion conducted since the mid-1990s (Pascual \& Adkison 1994, York 1994, Holmes \& York 2003, Fay \& Punt 2006, Winship \& Trites 2006, Holmes et al. 2007) is that the decline in abundance observed in the 1980s and early 1990s was associated with a large drop in the survival rate of juvenile sea lions. Empirical evidence from animals marked as pups in the central Gulf of Alaska in 1987-1988 supports these model results: juvenile survival rates were $21 \%$ lower in the late 1980s and early 1990s than in the mid-1970s (York 1994, Pendleton et al. 2006), which is similar to demographic model estimates of juvenile female survival for this period reported by Holmes et al. (2007) (Fig. 4). The slower rate of population decline in the central Gulf observed in the 1990s and the population stability of the 2000 s were associated with increases in juvenile survival (Holmes et al. 2007, Fritz et al. 2013). Our empirical results indicate that juvenile survival in the 2000s is higher than in the late 1980s and early 1990s (Pendleton et al. 2006, Holmes et al. 2007), but may still be slightly lower than in the 1970s (Calkins \& Pitcher 1982, York 1994, Holmes et al. 2007)

There has been less agreement among model results in the magnitude of the changes that have occurred in adult survivorship and natality, though all models indicated declines in both for various lengths of time. Models that included data collected through the 1990s and early 2000s (Holmes \& York 2003, Fay \& Punt 2006, Winship \& Trites 2006, Holmes et al. 2007) revealed that the steep population decline of the 1980s was associated with a large drop in juvenile survival and usually modest declines in both adult survival and natality. However, as the population decline slowed in the 1990s and increased slightly in the early 2000s, juvenile and adult survival improved, but results were mixed regarding changes (if any) in natality.

Holmes et al. (2007) observed a marked and continuous decline in natality in the central Gulf Steller sea lion population, and our Leslie model results support this conclusion if we too assume that this population 


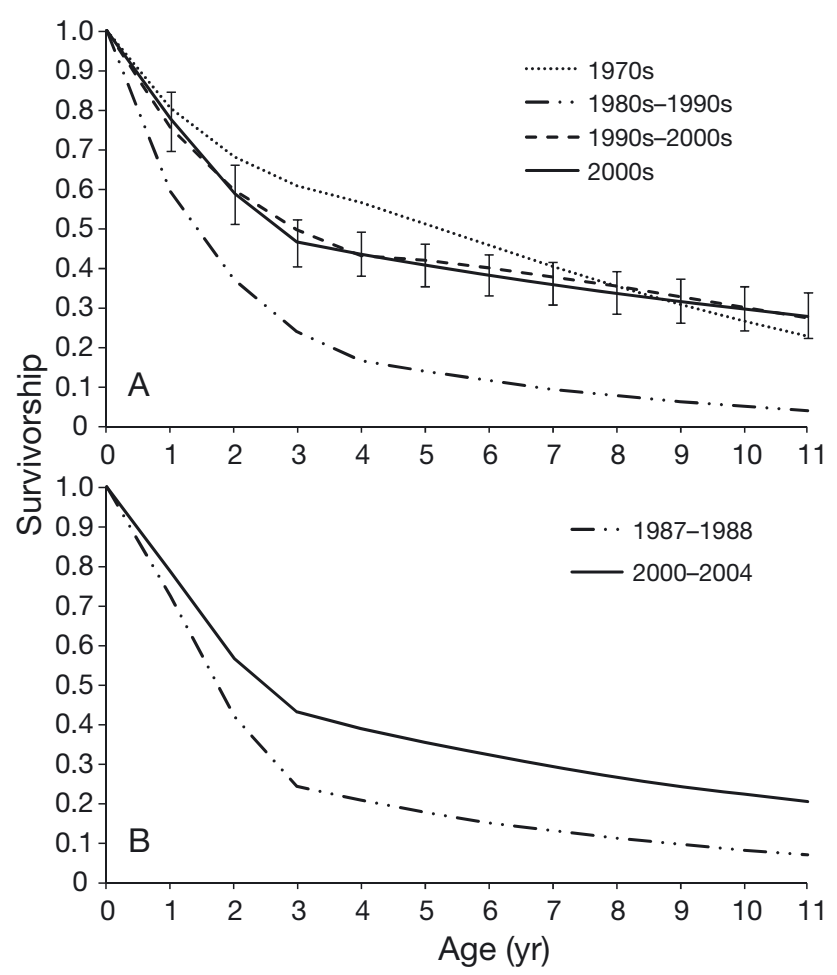

Fig. 4. Survivorship of Steller sea lions in the central Gulf of Alaska, 1970s through 2000s. (A) Females in the mid-1970s based on a life table (1970s; Calkins \& Pitcher 1982, Holmes et al. 2007); modeled female populations in the late 1980s and early 1990s (1980s-1990s), and late 1990s and early 2000s (1990s-2000s; Holmes et al. 2007); and females branded as pups in 2000-2004 (2000s with 95\% confidence bounds; present study). (B) Pooled females and males branded as pups in 1987-1988 (1987-1988; Pendleton et al. 2006); and pooled females and males branded as pups in 2000-2004 (2000-2004; present study)

is closed. However, the closed population assumption does not appear to be valid for the recent (since 2000) period (Fritz et al. 2013). When this region is combined with the eastern Gulf as the animal movement data suggest, the perception is that natality may only be slightly lower now in the combined region than in the $1970 \mathrm{~s}$. While it is not possible to determine whether movement from the central Gulf of Alaska to the eastern Gulf is a new phenomenon, perhaps in response to the severe decline experienced through the 1990s, the growth of the western Steller sea lion stock east of Samalga Pass may not be due to increased survival alone. However, there are several caveats to our analysis that preclude this from being a firm conclusion. First, survival estimates were treated as fixed and known in the Leslie model, and uncertainty in the survival values was not propagated to uncertainty in natality. Second, the overall shape of the natality curve was assumed to be the same as the 1970s population (Holmes et al. 2007). If the actual shape of the schedule has changed (e.g. not as strong a drop in natality with age), the procedure employed here might increase the overall curve in an effort to increase natality in a particular part of the curve. Given that senescence has been observed in some (A. pusillus pusillus, Butterworth et al. 1995; Z. californianus, Hernandez-Camacho et al. 2008; C. ursinus, Lander 1981-1982) but not all (Arctocephalus gazella, Boyd et al. 1995) otariids, this assumption will be tested and empirical estimates of natality will be obtained as sightings of our study animals are obtained in subsequent years. Third, the age distribution used for the initial year in the model will affect the results. The assumption used here of a stable age distribution in 2000 may not be accurate given the large changes in abundance in the 2 previous decades (Fritz et al. 2013).

Our new empirical and model results for western Steller sea lion survival and natality indicate that where population trends are positive (east of Samalga Pass), vital rates have returned to nearly the same levels estimated for the mid-1970s prior to the steep decline in abundance. Increases in abundance in this area are responsible for the positive trend observed since 2000 in the western stock in Alaska overall (Fritz et al. 2013). The results of the Leslie matrix modeling undertaken in this study are not intended to be used to forecast regional population growth, but were simply used to compare natality schedules estimated for a 1970s stable population with those estimated for variably increasing populations, all east of Samalga Pass, in the period 20002012, as a follow-on to Holmes et al. (2007). There is no information, however, on Steller sea lion vital rates west of Samalga Pass where counts of pups and non-pups continued to decline through 2012 (Fay \& Punt 2013, Fritz et al. 2013, Johnson \& Fritz 2014).

There are 2 demographic criteria, along with the listing criteria, that must be met before NMFS considers changing the listing status of western Steller sea lions from 'endangered' to 'threatened' (NMFS 2008). The first is a statistically significant increase in abundance for the Alaska western stock as a whole over a $15 \mathrm{yr}$ period beginning in 2000, when the lowest abundance count was made (NMFS 2008). The western stock appears to be on track to meet the first down-listing criterion by 2015 if abundance trends estimated through 2012 continue (Fritz et al. 2013, NMFS unpubl. data). The second demographic downlisting criterion states that trends in at least 5 of 7 western regions (6 in Alaska and 1 in Russia) must be 'consistent' with the overall stock trend, with the 
added stipulation that trends cannot be declining in any 2 adjacent regions (NMFS 2008). Given trends observed in most of the Aleutian Islands (which include 2 of the 6 Alaska regions), it is unclear whether the western stock will meet the second criterion by 2015. Research will continue on understanding the possible causes of the continued decline west of Samalga Pass, which include nutritional stress related to environmental change or fisheries (NRC 1996, 2003, NMFS 2000, 2008, 2010, Malavear 2002, Trites \& Donnelly 2003, Fritz \& Hinckley 2005, Trites et al. 2007, Atkinson et al. 2008), predation by killer whales (Springer et al. 2003, Williams et al. 2004, Maniscalco et al. 2007, Horning \& Mellish 2012), contaminants and disease that could impair reproduction (Burek et al. 2003, Atkinson et al. 2008, Castellini et al. 2012), and incidental and intentional takes in Russian fisheries (Burkanov et al. 2006).

Acknowledgements. We thank K. Call, B. Fadely, S. Finneseth, C. Gudmundson, M. Lander, J. Sease, J. Sterling, K. Sweeney, J. W. Testa, J. Thomason, A. York, and others in the Alaska Ecosystem Program, NMML, who assisted in branding and sighting of marked animals. In particular, we thank the hardy souls who camped on Marmot and Ugamak Islands for 2 months each summer. In addition, we thank our collaborators at Alaska SeaLife Center, Alaska Department of Fish and Game, US Fish and Wildlife Service, US National Park Service, as well as members of the public who provided sighting information. We also recognize R. Merrick and D. Calkins, who initiated NMML's branding program in the late 1980s at Marmot Island, and whose work was instrumental in the design of the present study. We thank the captains and crews of the RV 'Tiglax', FV 'Aleutian Mariner', FV 'Bristol Mariner', RV 'Waters', RV 'Norseman' and RV 'Norseman II'. Constructive comments by J. Baker, J. Laake, S. Melin, J. W. Testa, and 4 anonymous reviewers were greatly appreciated and improved the manuscript significantly $(\mathrm{p}<0.01)$. Research was conducted under authority of US Marine Mammal Protection Act/Endangered Species Act Permits 782-1532, 782-1768, 782-1889, and 14326, and NMFS IACUC Protocol A/NW2010-04. We dedicate this to Capt. Gary Edwards and the crew members of the FV 'Big Valley'.

\section{LITERATURE CITED}

Atkinson S, DeMaster DP, Calkins DG (2008) Anthropogenic causes of the western Steller sea lion Eumetopias jubatus population decline and their threat to recovery. Mammal Rev 38:1-18

Bartholomew GA (1970) A model for the evolution of pinniped polygyny. Evolution 24:546-559

> Bickham JW, Patton JC, Loughlin TR (1996) High variability for control-region sequences in a marine mammal: implications for conservation and biogeography of Steller sea lions (Eumetopias jubatus). J Mammal 77:95-108

Boyd I, Croxall JP, Nunn NJ, Reid K (1995) Population demography of Antarctic fur seals: the costs of reproduc- tion and implications for life-histories. J Anim Ecol 64: 505-518

Braham HW, Everitt RD, Rugh DJ (1980) Northern sea lion decline in the eastern Aleutian Islands. J Wildl Manag 44:25-33

Burek KA, Gulland FMD, Sheffield G, Calkins D and others (2003) Disease agents in Steller sea lions in Alaska: a review and analysis of serology data from 1975-2000. Research Reports 11:4. The Fisheries Centre, University of British Columbia, Vancouver

Burkanov VN, Loughlin TR (2005) Historical distribution and abundance of Steller sea lions on the Asian coast. Mar Fish Rev 67:1-62

Burkanov VN, Trukhin AM, Johnson D (2006) Accidental bycatch of Steller sea lions (Eumetopias jubatus) in the western Bering Sea herring (Clupea harengus) trawl fishery. In: Collection of Scientific Papers, Marine Mammals of the Holoarctic, 4th Int Conf, St. Petersburg, Russia, 10-14 September 2006, p 117-119

Burnham KP, Anderson DR (2002) Model selection and multimodel inference: a practical-theoretic approach, 2nd edn. Springer-Verlag, New York, NY

> Butterworth DS, Punt AE, Oosthuizen WH, Wickens PA (1995) The effects of future consumption by the Cape fur seal on catches and catch rates of the Cape hakes. 3. Modeling the dynamics of the Cape fur seal Arctocephalus pusillus pusillus. S Afr J Mar Sci 16:161-183

Calkins DG, Pitcher KW (1982) Population assessment, ecology and trophic relationships of Steller sea lions in the Gulf of Alaska. In: Calkins DG, Pitcher KW, Schneider KB, Murray N (eds) Environmental assessment of the Alaskan continental shelf. US Department of Commerce and US Department of the Interior, Final Report Principal Investigators, 19:1-565, p 447-546

Castellini JM, Rea LD, Lieske CL, Beckmen KB, Fadely BS, Maniscalco JM, O'Hara TM (2012) Mercury concentrations in hair from neonatal and juvenile Steller sea lions (Eumetopias jubatus): implications based on age and region in this northern Pacific marine sentinel piscivore. EcoHealth 9:267-277

Conn PB, Johnson DS, Fritz LW, Fadely BS (2014) Examining the utility of fishery and survey data to detect prey removal effects on Steller sea lions (Eumetopias jubatus). Can J Fish Aquat Sci 71(8):1229-1242

> Dalton R (2005) Animal-rights group sues over 'disturbing' work on sea lions. Nature 436:315

Fay G, Punt AE (2006) Modeling spatial dynamics of Steller sea lions (Eumetopias jubatus) using maximum likelihood and Bayesian methods: evaluation causes for population decline. In: Trites AW, Atkinson SK, DeMaster DP, Fritz LW, Gelatt TS, Rea LD, Wynne KM (eds) Sea lions of the world. Proc Symp Sea Lions of the World: Conservation and Research in the 21st Century, 30 September3 October 2004, Anchorage, AK, USA. Alaska Sea Grant College Program, University of Alaska Fairbanks, p 405-434

Fay G, Punt AE (2013) Methods for estimating spatial trends in Steller sea lion pup production using the Kalman filter. Ecol Appl 23:1455-1474

Ferrero RC, Fritz LW (2002) Steller sea lion research coordination: a brief history and summary of recent progress. US Department of Commerce, NOAA Tech Memo NMFS-AFSC-129

Fritz LW, Hinckley S (2005) A critical review of the regime shift — 'junk food' — nutritional stress hypothesis for the 
decline of the western stock of Steller sea lion. Mar Mamm Sci 21:476-518

Fritz LW, Ferrero RC, Berg RJ (1995) The threatened status of Steller sea lions, Eumetopias jubatus, under the Endangered Species Act: effects on Alaska groundfish fisheries. Mar Fish Rev 57:14-27

Fritz L, Sweeney KS, Johnson DS, Lynn M, Gilpatrick J (2013) Aerial, ship, and land-based surveys of Steller sea lions (Eumetopias jubatus) in Alaska, June and July 2008-2012. US Department of Commerce, NOAA Tech Memo NMFS-AFSC-251

> Hastings KK, Jemison LA, Gelatt TS, Laake JL and others (2011) Cohort effects and spatial variation in age-specific survival of Steller sea lions from southeastern Alaska. Ecosphere 2:art111

Hastings KK, Gelatt TS, King JC (2009) Postbranding survival of Steller sea lion pups at Lowrie Island in Southeast Alaska. J Wildl Manag 73:1040-1051

Hernandez-Camacho CJ, Aurioles-Gamboa D, Laake J, Gerber LR (2008) Survival rates of the California sea lion, Zalophus californianus, in Mexico. J Mammal 89: 1059-1066

> Holmes EE, York AE (2003) Using age structure to detect impacts on threatened populations: a case study with Steller sea lions. Conserv Biol 17:1794-1806

Holmes EE, Fritz LW, York AE, Sweeney K (2007) Age-structured modeling reveals long-term declines in the natality of western Steller sea lions. Ecol Appl 17:2214-2232

Horning M, Mellish JAE (2012) Predation on an upper trophic marine predator, the Steller sea lion: evaluating high juvenile mortality in a density-dependent conceptual framework. PLoS ONE 7:e30173

Johnson DS, Fritz LW (2014) agTrend-A Bayesian approach for estimating trends of aggregated abundance. Methods Ecol Evol, doi: 10.1111/2041-210X.12231

Laake JL, Rexstad DE (2007) RMark - an alternative approach to building linear models. Appendix C. In: Cooch E, White G (eds) Program MARK, 'A gentle introduction'. Available at www.phidot.org/software/mark/docs/book/

> Lander RH (1981-1982) A life table and biomass estimate for Alaskan fur seals. Fish Res 1:55-70

Loughlin TR (1997) Using the phylogeographic method to identify Steller sea lion stocks. In: Dizon AE, Chivers SJ, Perrin WF (eds) Molecular genetics of marine mammals. Soc Mar Mammal Spec Publ 3, Society for Marine Mammalogy, San Francisco, CA, p 159-171

Loughlin TR, Perlov AS, Vladimirov VA (1992) Range-wide survey and estimation of total number of Steller sea lions in 1989. Mar Mamm Sci 8:220-239

Lowry LF, Frost KJ, Calkins DG, Swartzman GL, Hills S (1982) Feeding habits, food requirements, and status of Bering Sea marine mammals. Final report to the North Pacific Fishery Management Council, Anchorage, AK. Contract No. 81-4

Malavear MYG (2002) Modeling the energetics of Steller sea lions (Eumetopias jubatus) along the Oregon coast. MSc thesis, Oregon State University, Corvallis, OR

> Maniscalco JM, Parker P (2009) A case of twinning and the care of two offspring of different ages in Steller sea lions. Mar Mamm Sci 25:206-213

> Maniscalco JM, Matkin CO, Maldini D, Calkins DG, Atkinson S (2007) Assessing killer whale predation on Steller sea lions from field observations in Kenai Fjords, Alaska. Mar Mamm Sci 23:306-321

Maniscalco JM, Springer AM, Parker P (2010) High natality rates of endangered Steller sea lions in Kenai Fjords, Alaska and perceptions of population status in the Gulf of Alaska. PLoS ONE 5:e10076

Mellish J, Hennen D, Thornton J, Petrauskas L, Atkinson S, Calkins D (2007) Permanent marking in an endangered species: physiological response to hot branding in Steller sea lions (Eumetopias jubatus). Wildl Res 34:43-47

Merrick RL, Loughlin TR, Calkins DG (1996) Hot branding: a technique for long-term marking of pinnipeds. US Department of Commerce, NOAA Tech Memo NMFSAFSC-68

National Marine Fisheries Service (NMFS) (1992) Final recovery plan for Steller sea lions Eumetopias jubatus. NMFS Office of Protected Resources, Silver Spring, MD

National Marine Fisheries Service (NMFS) (2000) Endangered Species Act, Section 7. Consultation, biological opinion and incidental take statement on the authorization of the Bering Sea/Aleutian Islands and Gulf of Alaska groundfish fishery Management Plans. NMFS Alaska Region, Protected Resources Division, Juneau, AK

National Marine Fisheries Service (NMFS) (2008) Recovery plan for the Steller sea lion (Eumetopias jubatus). Revision. National Marine Fisheries Service, Silver Spring, MD

National Marine Fisheries Service (NMFS) (2010) Endangered Species Act, Section 7. Consultation, biological opinion and incidental take statement on the authorization of the Bering Sea/Aleutian Islands and Gulf of Alaska groundfish fishery Management Plans. NMFS Alaska Region, Protected Resources Division, Juneau, AK

National Marine Fisheries Service (NMFS) (2013) Status review of the eastern distinct population segment of Steller sea lion (Eumetopias jubatus). Protected Resources Division, Alaska Region, National Marine Fisheries Service, Juneau, AK

National Research Council (NRC) (2003) Decline of the Steller sea lion in Alaskan waters: untangling food webs and fishing nets. National Academy Press, Washington, DC

National Research Council (NRC) (1996) The Bering Sea ecosystem. Committee on the Bering Sea Ecosystem, National Academy Press, Washington, DC

Pascual MA, Adkison MD (1994) The decline of the Steller sea lion in the northeast Pacific: demography, harvest or environment. Ecol Appl 4:393-403

Pendleton GW, Pitcher KW, Fritz LW, York AE and others (2006) Survival of Steller sea lions in Alaska: a comparison of increasing and decreasing populations. Can J Zool 84:1163-1172

Pike GC, Maxwell BE (1958) The abundance and distribution of the northern sea lion (Eumetopias jubata [sic]) on the coast of British Columbia. J Fish Res Board Can 15:5-17

Pitcher KW, Calkins DG (1981) Reproductive biology of Steller sea lions in the Gulf of Alaska. J Mammal 62: 599-605

Pitcher KW, Burkanov VN, Calkins DG, LeBoeuf BJ, Mamaev EG, Merrick RL, Pendleton GW (2001) Spatial and temporal variation in the timing of births of Steller sea lions. J Mammal 82:1047-1053

Pitcher KW, Olesiuk PF, Brown RF, Lowry MS and others (2007) Abundance and distribution of the eastern North Pacific Steller sea lion (Eumetopias jubatus) population. Fish Bull 107:102-115 
R Development Core Team (2013) R: A language and environment for statistical computing. R Foundation for Statistical Computing, Vienna, Austria. www.r-project.org

Raum-Suryan KL, Pitcher KW, Calkins DG, Sease JL, Loughlin TR (2002) Dispersal, rookery fidelity and metapopulation structure of Steller sea lions (Eumetopias jubatus) in an increasing and a decreasing population in Alaska. Mar Mamm Sci 18:746-764

Springer AM, Estes JA, van Vliet GB, Williams TM and others (2003) Sequential megafaunal collapse in the North Pacific Ocean: an ongoing legacy of industrial whaling? Proc Natl Acad Sci USA 100:12223-12228

Thorsteinson FV, Lensink CJ (1962) Biological observations of Steller sea lions taken during an experimental harvest. J Wildl Manag 26:353-359

Trites AW, Donnelly CP (2003) The decline of Steller sea lions Eumetopias jubatus in Alaska: a review of the nutritional stress hypothesis. Mammal Rev 33:3-28

Trites AW, Miller AJ, Maschner HDG, Alexander MA and others (2007) Bottom-up forcing and the decline of Steller sea lions (Eumetopias jubatas) in Alaska: assessing the ocean climate hypothesis. Fish Oceanogr 16:46-67

White GC, Burnham KP (1990) Program MARK - survival

Editorial responsibility: Simon Goldsworthy,

West Beach, Australia estimation from populations of marked animals. Bird Study 46:1-31

Williams TW, Estes JA, Doak DF, Springer AM (2004) Killer appetites: assessing the role of predators in ecological communities. Ecology 85:3373-3384

Wilson K, Fritz L, Kunisch E, Chumbley K, Johnson D (2012) Effects of research disturbance on the behavior and abundance of Steller sea lions (Eumetopias jubatus) at two rookeries in Alaska. Mar Mamm Sci 28:E58-E74

- Winship AJ, Trites AW (2006) Risk of extirpation of Steller sea lions in the Gulf of Alaska and Aleutian islands: a population viability analysis based on alternative hypotheses for why sea lions declined in western Alaska. Mar Mamm Sci 22:124-155

> Winship AJ, Trites AW, Calkins DG (2001) Growth in body size of the Steller sea lion (Eumetopias jubatus). J Mammal 82:500-519

York A (1994) The population dynamics of the northern sea lions, 1975-85. Mar Mamm Sci 10:38-51

York AE, Merrick RL, Loughlin TR (1996) An analysis of the Steller sea lion metapopulation in Alaska. In: McCullough DR (ed) Metapopulations and wildlife conservation. Island Press, Washington, DC, p 259-292

Submitted: May 14, 2013; Accepted: July 10, 2014

Proofs received from author(s): October 6, 2014 